Dr IVANA DOBRIVOJEVIĆ TOMIĆ, viši naučni saradnik

Institut za savremenu istoriju

Beograd, Republika Srbija

ivanadobrivojevic@hotmail.com

UDK 316.728-054.72(497.113)"1945/1953"

314.15-026.48-054.72(497.113)"1945/1953"

originalan naučni rad / original scientific paper

primljeno / received: 15. 2. 2021.

prihvaćeno / accepted: 19. 5. 2021.

https://doi.org/10.29362/ist20veka.2021.2.dob.313-332

\title{
PROBLEMI U NASELJAVANJU I PRILAGOĐAVANJU KOLONISTA NA ŽIVOT U VOJVODINI U PRVIM GODINAMA POSLE DRUGOG SVETSKOG RATA
}

APSTRAKT: Članak razmatra probleme u preseljavanju preko 200.000 stanovnika u Vojvodinu i prilagođavanje kolonista, pristiglih uglavnom iz neplodnih, planinskih regiona Jugoslavije na život u ravnici. Posebna pažnja je posvećena putovanju, podeli zemlje i kuća, organizovanju ishrane, teškoćama u navikavanju na nove uslove života i povratku jednog dela porodica u stari kraj. Rad je zasnovan na izvorima koji se čuvaju u Arhivu Jugoslavije, periodici i relevantnoj literaturi.

KLJUČNE REČI: Jugoslavija, Vojvodina, migracije, kolonisti, autokolonisti

\section{Pripreme za kolonizaciju}

Odluka AVNOJ-a o konfiskaciji imovine u vlasništvu Nemaca (1944), ${ }^{1} \mathrm{Za}-$ kon o agrarnoj reformi i kolonizaciji (avgust 1945) ${ }^{2}$ i Uredba o sprovođenju naseljavanja boraca $(1945)^{3}$ predstavljali su pravni okvir kojim je omogućeno i zakonski uređeno preseljavanje u Vojvodinu. Pored zemlje konfiskovane od Nemaca, u novoformirani zemljišni fond ušle su i oranice i šume oduzete od crkava, manastira, banaka, velikih korporacija, veleposednika i imućnijih seljaka. Na teritoriji Bačke, Banata, Srema i Baranje država je raspolagala sa 500.000 katastarskih jutara, odnosno oko 287.500 hektara oduzete zemlje na koju je trebalo naseliti 45.000 porodica, uglavnom iz siromašnih brdsko-planinskih regiona. Uredbom o redu prvenstva $u$

\footnotetext{
${ }^{1}$ Службени лист ДФЈ, бр. 2, 1945.

2 „Закон о аграрној реформи и колонизацији“, Службени лист ДФЈ, 64, 1945. Videti i: Nikola Gaćeša, Agrarna reforma i kolonizacija u Jugoslaviji 1945-1948 (Novi Sad: Matica srpska, 1984), 109-114; Branko Petranović, Političke i pravne prilike za vreme privremene vlade DFJ (Beograd: Institut društvenih nauka, 1964), 57-58; Момчило Митровић, Друштвеноекономске промене и организација управљања привиредом у Србији 1944-1952 (Београд: Институт за историју радничког покрета Србије, 1988), 248-251; Вера Гудац Додић, Аграрна политика и сељаштво у Србији 1945-1953 (Београд: Завод за уџбенике и наставна средства, 1999), 26-28; Богдан Лекић, Аграрна реформа и колонизација у Југославији 1945-1948 (Београд: Архив Србије, 1997), 66-89.

3 „Уредба о спровођењу насељавања бораца у Војводини“, Службени лист ДФЈ, бр. 72, 1945.
} 
dodeljivanju zemlje prednost je data borcima i invalidima, porodicama nastradalih boraca i licima koje su neprijateljski vojnici hapsili, mučili, osuđivali, internirali ili držali u zarobljeništvu, kao i porodicama žrtava. ${ }^{4}$

Donošenje propisa o kolonizaciji u najsiromašnijim krajevima Jugoslavije shvaćeno je kao poziv na masovne migracije. Najveće interesovanje za preseljenje vladalo je među srpskim življem u Bosni i Hercegovini. ${ }^{5}$ Nastalo je ,pprosto jedno otimanje za odlazak u Vojvodinu“, pa su molbe za kolonizaciju popunjavali gotovo svi, bez obzira na imovinsko stanje. ${ }^{6}$ Iako su centralni organi vlasti procenjivali da ,država neće moći naseljenike pomoći onoliko koliko je potrebno da se u prvo vreme dobro snađu“, 7 u pasivnim regionima verovalo se da selidba u Vojvodinu garantuje izbavljenje iz decenijske oskudice i siromaštva. Poneseni pričama o vojvođanskom blagostanju koje su nekritički širili lokalni funkcioneri, za kolonizaciju su se prijavljivali čak i oni koji u ratu nisu učestvovali. Veliko interesovanje vladalo je i u Lici, Baniji, Kordunu i Crnoj Gori, pa je do novembra 1945. na području čitave države (bez Bosne i Hercegovine za koju nema podataka) predato nešto preko 57.000 molbi. ${ }^{8}$ Kolonizacija je otvorila put migracijama koje nije bilo moguće u potpunosti kontrolisati. Iseljavana su čitava plemena, poput 30 porodica Mandića iz Gackog, kao i velike kućne zadruge od 20 do 36 članova. Prema podacima Glavne komisije za naseljavanje boraca, ovim zadrugama je naređivano da se potpuno isele, iako je imanje jednoj užoj porodici moglo obezbediti pristojan život. ${ }^{9}$ Nisu pomagali ni apeli saveznih organa koji su uzaludno upozoravali vlasti u Bosni i Hercegovini da se iz nekih područja iseljava više stanovništva nego što je to potrebno i da je takav egzodus štetan po republičke, ali i državne, ekonomske i političke interese. ${ }^{10}$

Prvobitno je planirano da se sprovođenje agrarne reforme na teritoriji Vojvodine odvija u tri faze. Zemljište je trebalo eksproprisati, podeliti agrarnim interesentima, a zatim nove svojinske odnose sankcionisati u zemljišnim knjigama. Međutim, ratna šteta koju su pretrpeli regioni iz kojih je stizao najveći broj demobilisanih boraca, veliko siromaštvo i nadolazeća zima predstavljali su neke od razloga koji su uticali da se kolonizaciji dâ apsolutni prioritet. Iako je zemljišni fond formiran od poseda prikupljenih eksproprijacijom i konfiskacijom, vlasti nisu čekale da se oduzimanje poseda i formalno završi. Zemljište je davano kolonistima bez preciznih podataka, a

\footnotetext{
${ }^{4}$ Arhiv Jugoslavije (AJ), fond 97, Komisija za agrarnu reformu i kolonizaciju, 1-1, Uredba o redu prvenstva u dodeljivanju zemlje, 2.9. 1945.

${ }^{5} \mathrm{~N}$. Gaćeša, $n . d$., 299; „Припреме у Херцеговини за исељавање 5.000 породица у Војводину“, Политика, 13. 9. 1945.

${ }^{6}$ Ivana Dobrivojević Tomić, „U potrazi za boljom budućnošću. Naseljavanje kolonista u prvim godinama nakon Drugog svetskog rata“, u: Drugi svetski rat - 75 godina kasnije, u pripremi za štampu.

${ }^{7}$ AJ, 97-3-30, Šta da se učini sa zemljom onih ljudi koji se budu preseljavali kao kolonisti?

${ }^{8}$ I. Dobrivojević Tomić, $n$. $d$. O interesovanju za kolonizaciju svedoči podatak iznet 3. avgusta 1945. na sednici Politbiroa CK KPH da „50\% Kordunaša hoće da se seli u plodnije krajeve“. Videti: Драгомир Бонџић, „Кордун у социјалистичкој Југославији (1945-1990)“, у: Кордун. Од Војне границе до Републике Српске Крајине 1881-1995, уредник Момчило Павловић (Београд: Институт за савремену историју, 2018), 357.

${ }^{9}$ AJ, 97-1-14, Br. 9, 2. januar 1946.

${ }^{10}$ I. Dobrivojević Tomić, $n . d$.
} 
imovina za koju su lokalni organi izveštavali da pripada ,licima nemačke narodnosti ili državnim neprijateljima deljena su bez daljeg kao zemljišta zemljišnog fonda“. Nedostatak tačnih podataka o novim svojinskim odnosima Glavna komisija za naseljavanje boraca premostila je blokirajući sve površine u katastarskim opštinama koje su kolonizovane u velikom obimu. Tek nakon završetka naseljavanja, nepodeljene oranice vraćene su u zemljišni fond ${ }^{11}$ što je dovelo do izvesne, mada neplanirane, favorizacije saveznih kolonista $u$ odnosu na druge agrarne interesente. ${ }^{12}$ Međutim, ovakvo postupanje nije samo izazivalo nezadovoljstvo u redovima onih koji su sebe smatrali oštećenim, već je prouzrokovalo i probleme pravne prirode. Neke od nekretnina koje su konfiskacijom prešle u državne ruke sudovi su vratili predratnim vlasnicima. Poteškoće su se javile i sa imovinom u vlasništvu Nemaca, američkih državljana, ali i Jevreja i „ostalih odsutnih lica“ koja je data kolonistima. Kako je zemljišni fond bio rasformiran 1947. godine, bilo je nemoguće naknadno vršiti korekcije. ${ }^{13}$ Štaviše, članom 10 Uredbe o sprovođenju naseljavanja boraca u Vojvodini predviđeno je da se zemlja može oduzeti samo u slučaju da se kolonista u roku od 20 godina od naseljavanja sa nje ,odseli ili je tako napusti da prestane njome upravljati i obrađivati je“. Stoga je Komitet za zakonodavstvo i izgradnju narodne vlasti konstatovao da, s obzirom na to da zemlja ne može biti oduzeta od kolonista, sudovi ne bi trebalo ni da donose odluke o vraćanju oranica ranijim vlasnicima. Zaključeno je da se donete sudske presude ,ne mogu izvršiti“", već da „,sopstvenike treba uputiti da traže naknadu u novcu“. Najveće žrtve ovog pravnog galimatijasa bili su zemljoradnici kojima su obradive površine nepravedno oduzete, a koji nadoknadu u novcu nisu želeli. Iako je previđeno da bi trebalo ,ispitati mogućnost“ da se njima dodeli imanje na nekom drugom mestu, ${ }^{14}$ na osnovu raspoloživih izvora teško je reći da li su ova lica, i pored važeće presude, obeštećena na zadovoljavajući način.

Nedostatak novca, velika oštećenja saobraćajnih komunikacija i prevoznih sredstava, teškoće u prijavljivanju i izdavanju dozvola za kolonizaciju predstavljali su neke od najvećih organizacionih i logističkih problema koje su savezne vlasti uspele da prebrode. Do proleća 1946. godine u Vojvodinu je preseljeno oko 37.000 porodica. ${ }^{15}$ Nove kolonističke naseobine nisu zidane, budući da se pošlo od stanovišta ,,da ima dovoljno konfiskovanih kuća“" u koje se novi doseljenici mogu useljavati. ${ }^{16}$ Svakoj grupi naseljenika davano je u potesima onoliko zemlje koliko je celom selu trebalo da pripadne, a Ministarstvo je naknadno tu zemlju delilo na individualne parcele. ${ }^{17}$

${ }^{11}$ AJ, 97-12-79, Autonomna pokrajina Vojvodina - podaci i izveštaj o stanju postupka agrarne reforme i unutrašnje kolonizacije od 8. 11. 1947.

${ }^{12}$ AJ, 97-12-80, Nezavedeno, bez datuma (1947. godina).

${ }^{13}$ AJ, fond 50, Predsedništvo FNRJ, 89-188, Pov. br. 1 od 1948 (6. 1. 1948).

${ }^{14}$ AJ, 97-14-93, Pov. br. 3, 21. 1. 1948.

${ }^{15}$ AJ, 97-9-60, Stanje kolonista u Vojvodini na dan 1. 5. 1946. godine. Međutim, kada je reč o ukupnom broju kolonista koji su preseljeni i njihovom teritorijalnom poreklu, različiti autori navode različite podatke. Više o tome: Жељко Бјељац и Александра Терзић, „Миграције на територији Војводине 19451948. Узроци и демографске последице“ у: 1945. Крај или нови почетак, уредник Зоран Јањетовић (Београд: Институт за новију историју Србије, Музеј жртава геноцида, 2016), 382-383.

${ }^{16}$ AJ, 97-3-30, Osnovni načelni stavovi o kolonizaciji u Vojvodini.

${ }^{17}$ AJ, 97-2-19, Br. 6611, 27. 8. 1945. 
Uz kuću, bilo je predviđeno da kolonisti dobiju okućnicu sa pomoćnim zgradama, a da se zemlja dâ u stalnu svojinu bez mogućnosti trgovine. ${ }^{18}$ Osim ekonomskih momenata, vlasti su razmišljale i o kulturološko-socijalnim, anticipirajući moguće probleme u prilagođavanju kolonista. „Svaki naseljenik nosi obeležje mentaliteta čoveka svoga kraja. Treba učiniti sve da se bez potrebe ne mešaju ljudi raznih osobina u pojedinim naseljima jer to otežava prilagođavanje i snalaženje u životu i radu“, konstatovano je u dokumentu Osnovni načelni stavovi o kolonizaciji u Vojvodini. ${ }^{19}$ Međutim, osim kulturoloških, i etnički i politički razlozi ${ }^{20}$ igrali su izvesnu ulogu u odluci da se lokalno stanovništvo naseli u mestima u kojima je, posle iseljavanja Nemaca, ostao deo starosedelačkog življa, a da se doseljenici iz ostalih krajeva grupišu prema poreklu u sela koja se iznova naseljavaju. ${ }^{21}$ Iako konfiguracija terena nije omogućavala da se kolonisti naseljavaju u predelima koji su reljefno slični njihovom zavičaju, naloženo je da se iz zdravstvenih razloga doseljenici iz planinskih oblasti Crne Gore nasele na ,najvišoj visoravni“, u severnoj Bačkoj, severno od velikog kanala. ${ }^{22}$

Pripremajući se za masovnu kolonizaciju, vlasti su donele veliki broj uputstava kako bi putovanje, dodela imovine i prehrana naseljenika prošli bez većih problema. Naročita pažnja posvećena je preseljavanju iz Bosne, Hercegovine, Like, Korduna, Primorja i Crne Gore, budući da je stanovništvo ovih oblasti najteže postradalo za vreme rata. Stoga je izrađen „,minimalan plan“ kojim je predviđeno da se iz ovih krajeva do kraja decembra 1945. preseli 21.000 porodica. Početak kolonizacije naseljenika iz Slovenije, delova Hrvatske, Srbije i Makedonije ostavljen je, u najboljem slučaju, za novembar 1945. ili za početak 1946. Ministarstvo saobraćaja je i prema takvom ,minimalnom“ planu imalo ozbiljne rezerve, budući da su vozovi mogli ući u Vojvodinu jedino preko mosta kod Novog Sada i trajektom kod Smedereva. Veliki broj nepoznanica otežavao je organizaciju preseljenja, pa su i svi izrađeni planovi bili okvirni. Trebalo je kolonizovati 45.000 porodica od kojih su se mnoge, bežeći od ratnih stradanja, nalazile van uobičajenog prebivališta. Štaviše, s obzirom na proces podnošenja i odobravanja molbi, Ministarstvo nije imalo niti je moglo imati podatke koliko će porodica kolonista biti iz kog sela, sreza i okruga. ${ }^{23}$ Nesnalaženje lokalnih vlasti dodatno je usložnjavalo situaciju čineći da proces kolonizacije u pojedinim segmentima bude neorganizovan i haotičan.

Prema Uputstvima za preseljenje, bez odobrenja Ministarstva za agrarnu reformu i kolonizaciju nijedna porodica nije mogla krenuti put Vojvodine. Zapreće-

\footnotetext{
${ }^{18}$ AJ, 97-3-30, Osnovni načelni stavovi o kolonizaciji u Vojvodini.

${ }^{19}$ Isto.

${ }^{20}$ AJ, 97-2-19, Br. 6611, 27. 8. 1945.

${ }^{21}$ Planom Agrarnog saveta određeno je da se u Banatu naseli 16.500 porodica i to 3.000 iz Slovenije, 2.000 iz Makedonije, 3.000 iz Srbije i 8.500 iz Bosne i Hercegovine. U Bačku je trebalo da dođe 20.000 porodica i to 7.000 iz Crne Gore, 7.500 iz Hrvatske, 3.000 iz Bosne i 2.500 iz Srbije. U Srem je trebalo naseliti po 500 porodica iz Bosne i Hercegovine, Hrvatske i Srbije. Ante Laušić, „Osnovne značajke kolonizacijskih procesa na jugoslavenskom području 1918 1948“, Migracijske teme, 5, br. 1, (1989), 36.

${ }^{22}$ AJ, 97-3-30, Osnovni načelni stavovi o kolonizaciji u Vojvodini.

${ }^{23}$ AJ, 97-3-36, Osnovni problemi dosadanjeg i budućeg preseljenja kolonista. O etapnom doseljavanju kolonista iz različitih republika videti: N. Gaćeša, $n$. d., 299-332.
} 
no je da će ,sve posledice samovlasnog pokretanja kolonista snositi organi koji su ovo naredili ili izvršili“،. Svaki naseljenik trebalo je sedam dana pred put da dobije informacije o vremenu polaska. ${ }^{24} \mathrm{Za}$ prevoz su korišćena sva raspoloživa sredstva. Državno automobilsko saobraćajno preduzeće moralo je na raspolaganje vlastima staviti kamione, ${ }^{25}$ a vojne jedinice su ustupale i konje, ${ }^{26}$ budući da su kolonisti do polaznih železničkih stanica prevoženi i zaprežnim kolima. ${ }^{27}$ Svakoj porodici dozvoljeno je da ponese do 1.000 kilograma ,što bolje upakovanih“ stvari ${ }^{28} \mathrm{i}$ da povede po jedno grlo krupne stoke. Ipak, odstupanja od ovih pravila bilo je na pretek. Kolonistima je, po naređenju ministra Sretena Vukosavljevića, zabranjivano da sa sobom vode ,rasne bosanske konje““ ${ }^{29}$ Usled pogrešnog tumačenja propisa, iseljenici iz Donjeg Lapca bili su sprečeni da prodaju stvari koje nisu mogli poneti na put. $^{30}$ Pojedini čelnici lokalnih narodnih odbora odlazili su u drugu krajnost, pa su kolonistima, u najboljoj nameri, govorili da ,ne treba sa sobom ništa da nose“" 31 čak ni ćebad i pokrivače, ${ }^{32}$ jer će u novom zavičaju dobiti sve. ${ }^{33}$ Najdalje su, čini se, otišle vlasti u Crnoj Gori koje su naseljenicima, preko lista Pobjeda, obećavale „kompletan nameštaj, konje, krave, svinje i više kokošaka““. ${ }^{34}$ Protiv nerealnih obećanja nije se bilo lako boriti, budući da je i Politika pisala o ,masivnim krevetima sa madracima, skupocenim otomanima i novim ormanima" koje su kolonisti zatekli u „Švapskim“ kućama. ${ }^{35}$ Shvatajući da priče o vojvođanskom blagostanju izazivaju kontraefekat, centralne vlasti su nemoćno konstatovale da ,narod nije dovoljno politički pripremljen“. Obećanja koja su „u dobroj nameri“ davali „odgovorni rukovodioci“" nisu bila u skladu sa realnim prilikama na terenu. Razočarani kolonisti, shvatajući da neće dobiti ni polovinu obećanog, smatrali su da se radi o nehatu ili nameri vlasti da im ne dodeli imovinu za koju su verovali da im po pravu pripada. ${ }^{36}$ Kako bi se snabdevanje inventarom koliko-toliko dovelo u red, Ministarstvo kolonizacije je januara 1946. poslalo dopis svim republičkim vladama u kome je zahtevano da se kolonistima kaže da sa sobom ponesu neophodan ručni alat, posteljinu, tekstil, neprerađenu vunu, vrtno semenje i sve što im je potrebno za baštu. ${ }^{37}$

\footnotetext{
24 AJ, 97-3-36, Uputstva za preseljenje kolonista; Vladimir Đurić, Najnovije naseljavanje Bačke kolonistima iz Hrvatske (Novi Sad: Matica srpska, 1960), 6.

25 AJ, 97-3-36, Br. 8191, 22. 10. 1945.

${ }^{26}$ AJ, 97-3-36, Br. 149, 29. 8. 1945.

${ }^{27}$ O razmerama transportnih poteškoća svedoči podatak da iz Makedonije, zbog velike udaljenosti sela od železnice, do polovine decembra 1945. nije poslata nijedna kompozicija sa kolonistima; AJ, 97-2-19.

${ }^{28}$ AJ, 97-2-36, Referat i plan o preseljenju kolonista.

${ }^{29}$ AJ, 97-3-30, Br. 7222/45, 29. 8. 1945.

${ }^{30}$ AJ, 97-3-36, Saslušanje od 29. 9. 1945.

31 AJ, 97-4-39, Br. 3701, 7. 12. 1945.

32 AJ, 97-3-36, Br. 3024, 26. 9. 1945.

33 AJ, 97-4-39, Br. 3701, 7. 12. 1945.

${ }^{34}$ AJ, 97-1-11, Ministru za Crnu Goru Savezne vlade drugu Milovanu Đilasu, 22. 9. 1945.

35 „Горштаци у равној земљи. Херцеговци из околине Стоца у Банатском селу Катарина“, Политика, 26. 9. 1945.

36 AJ, 97-4-39, Br. 3701, 7. 12. 1945.

${ }^{37}$ AJ, 97-5-43, Br. 446, 21. 1. 1946.
} 
Organi unutrašnjih poslova trebalo je da vode računa da svi kolonisti budu blagovremeno prevezeni do zbornih stanica, da obezbede red prilikom ukrcavanja $\mathrm{i}$ da spreče da se ,oni koji nemaju pravo... koriste blagodetima Zakona o kolonizaciji““. ${ }^{38} \mathrm{Na}$ železničkim stanicama organizovana je ishrana, ali i dezinfekcija, dezinsekcija, deratizacija i kupanje kolonista ne bi li se sprečilo prenošenje pegavog tifusa. ${ }^{39} \mathrm{O}$ obimu sprovedenih sanitarnih mera teško je suditi na osnovu raspoloživih izvora. One su varirale od mesta do mesta i republike do republike, a morale su zavisiti i od broja raspoloživog medicinskog osoblja ili priučenog kadra. Odeljenje za agrarnu reformu i kolonizaciju pri Ministarstvu poljoprivrede i šumarstva NR Hrvatske nabavilo je ,najnužniji sanitetski materijal“" i angažovalo „,dovoljan broj lekara i bolničara“ koji su pratili „,svaki veći transport“ do Novog Sada i po potrebi ukazivali pomoć kolonistima. Postojanje jednog takvog sanitetskog vagona ${ }^{40}$ u pojedinim kompozicijama u mnogome je olakšavalo putovanje. U vozovima je bilo dece $\mathrm{i}$ trudnica ${ }^{41}$ ali i kolonista narušenog zdravlja pa su mnogi na putu dobijali upalu pluća, a neki su čak i umirali. ${ }^{42}$

\section{Put u nepoznato}

Uprkos jasnim naređenjima vlasti da se vozovi ,što više iskoriste“ ${ }^{43}$ svaka porodica je nastojala da putovanje provede sama u vagonu. ${ }^{44}$ Tokom septembra 1945. preseljavanja su vršena tako što su ,ljudi prosto na poziv prikupljeni, od oka određene porodice koje će ići, utovarene u vagone i preseljene“. U opštem metežu, mnogi nisu stigli da se na vreme ukrcaju u kompozicije, a pojedinci su odlučivali da odu sami ili sa delom porodice, a da se kasnije vrate po ostale članove. $^{45}$ Zbog žurbe u kojoj su preseljenja vršena, nije prolazio dan a da se nekoliko kolonista ne obrati Ministarstvu molbom da im se izdaju vozne karte kako bi se vratili u zavičaj da privedu kraju neki posao ili dovedu stoku i druge članove porodice. $^{46}$ Iako je loša organizacija putovanja u mnogim slučajevima predstavljala osnovni razlog zbog koga su kolonisti morali tražiti da im se plati put nazad Ministarstvo je, verovatno pre svega iz finansijskih razloga, takve molbe odbijalo uz obrazloženje da ,svakom kolonisti sleduje samo po jedna karta““. ${ }^{47}$

Putovanje kolonista pratile su brojne ,teškoće koje su iseljenici morali da trpe “ usled loše organizacije, čestog menjanja planova $\mathrm{i}$,nedovoljne pripre-

\footnotetext{
${ }^{38}$ AJ, 97-3-30, Br. 3626, 4. 9. 1945.

39 AJ, 97-2-36, Referat i plan o preseljenju kolonista; AJ, 97-9-61, Godišnji izveštaj o radu Ministarstva poljoprivrede i šumarstva Narodne republike Hrvatske, odjela za agrarnu reformu i kolonizaciju za period 12. 9. 1945 - 30. 10. 1946; М. Митровић, н. д., 268-269.

${ }^{40}$ AJ, 97-9-61, Godišnji izveštaj o radu Ministarstva poljoprivrede i šumarstva Narodne republike Hrvatske, odjela za agrarnu reformu i kolonizaciju za period 12. 9. 1945 - 30. 10. 1946.

41 AJ, 97-5-44, Br. 202, 8. 1. 1946.

${ }^{42}$ AJ, 97-3-36, Br. 12400, 22. 12. 1945.

43 AJ, 97-3-36, Uputstva za preseljenje kolonista.

44 AJ, 97-3-36, Br. 214, 26. 10. 1945.

45 AJ, 97-3-36, Br. 3024, 26. 11. 1945.

${ }^{46}$ AJ, 97-3-36, Osnovni problemi dosadanjeg i budućeg preseljenja kolonista.

47 AJ, 97-3-36, Br. 11545, 3. 12. 1945.
} 
me transporta“. ${ }^{48}$ Loše saobraćajne veze, nepotrebno čekanje na pruzi i loša koordinacija produžavali su putovanje, pa su kolonisti u vozovima provodili od dva do deset dana. ${ }^{49}$ Od Slavonskog Broda do Novog Sada putovalo se „tri četiri dana“, a redovno se dešavalo da se na pruzi Beograd-Zagreb stoji više sati. Od Inđije do teretne stanice u Novom Sadu stizalo se za 12 sati, a toliko je ponekad trebalo i kompoziciji da se iz Petrovaradina prebaci u Novi Sad. ${ }^{50}$ Istinski haos, međutim, nastajao je na novosadskoj stanici budući da su predstavnici Komisije za naseljavanje boraca šturo informisali osoblje u koji kraj treba naseliti koloniste iz nekog sreza. Posle ovakvih obaveštenja, železničari su bili prinuđeni da idu od vagona do vagona i da se raspituju kod putnika odakle je ko kako bi mogli da ,vrše manevar i sređivanje vozova“" 51

Glavna uprava železnica je, mimo dogovora sa Ministarstvom kolonizacije, samovoljno menjala planove polaska „svakih nekoliko dana“. ${ }^{52}$ Bilo je i slučajeva da železničari jednostavno zaborave na koloniste, prouzrokujući tako nepotrebna kašnjenja i čekanja na pruzi. Voz iz Višegrada stajao je u Lajkovcu 28 sati. $^{53}$ Ništa bolje nisu prošli ni Crnogorci koji su krajem novembra 1945. krenuli iz Bara i sa Cetinja. Zbog nemara, u Zeleniki su čekali tri dana, u Bosanskom Brodu još dan, u Vinkovcima 8 sati i u Mitrovici još 12. Tokom transporta jedan iseljenik je umro, a još osmoro njih je dobilo upalu pluća. Zbog nedostatka putničkih vozova, kolonisti i invalidi prevoženi su po najvećoj zimi otvorenim vagonima predviđenim za transport stoke. ${ }^{54}$ Za promrzle, slabo uhranjene i loše obučene ljude čini se da duž puta niko nije imao empatije. Na pritužbe o dugom čekanju, šefovi železničkih stanica su im povišenim tonom odgovarali da mogu i ,da idu pešice u Vojvodinu“. 55

Nepromišljenost i nemar skupo su plaćeni kada se u noći između 18. i 19. decembra 1945. dogodila velika nesreća u kojoj se 15 ljudi ugušilo ugljen monoksidom, a još devetoro je zbog trovanja moralo da bude prevezeno u bolnicu. Naime, železničari koji su prebacivali putnike iz Bosne kod Slavonskog Broda upotrebili su specijalno ojačan vagon za prevoz mesa koji je spolja hermetički zatvoren. Uprkos molbama kolonista da se vagon ne zatvara jer su u njemu imali naloženu peć, službenici su bili neumoljivi. Kada su, posle tri sata, na intervenciju kolonista iz drugih vagona, ova kola otvorena, sve je sačekala jeziva slika: na podu je ležalo 25 osoba bez svesti. Na zidovima vagona videli su se tragovi udaraca sekira kojima su nesrećni ljudi pokušavali da dozovu pomoć. OZNA je uhap-

48 AJ, 97-3-36, Br. 954, 24. 12. 1945.

${ }^{49}$ I. Dobrivojević Tomić, $n$. $d$.; N. Gaćeša, $n$. $d$., 299-301.

${ }^{50}$ AJ, 97-1-10, Izveštaj o radu do 30. septembra 1945.

${ }^{51}$ AJ, 95-5-44, Br. 26 600/45, 15. 1. 1946.

${ }^{52}$ AJ, 97-3-36, Telegram Delegata Ministarstva kolonizacije u Sarajevu - Glavnoj upravi železnica, 5. 11. 1945.

${ }^{53}$ AJ, 97-3-36, Br. 12 416, 22. 12. 1945.

${ }^{54}$ I. Dobrivojević Tomić, $n$. $d$. Videti i: Милован Бошковић и Митар Шутић, Два завичаја. Докуменат о једној сеоби. Поводом 60 година насељавања Гајдобре (Гајдобра: Огранак Вукове задужбине, 2005), 175.

${ }^{55}$ AJ, 97-3-36, Pismo Angeline Savić, šefa odseka za preseljenje - ministru kolonizacije. 
sila sedam železničkih službenika, a vlada Bosne i Hercegovine je formirala posebnu komisiju koja je trebalo da ispita incident. Da li je svih devetoro povređenih i preživelo, na osnovu raspoloživih izvora nemoguće je reći. ${ }^{56}$

Približavanjem zime 1945/46. godine, put Vojvodine kretalo je sve više kolonista koji su umesto dozvole za naseljavanje sa sobom donosili samo uverenje sreskog ili mesnog narodnog odbora da su siromašni i da im je potrebno dodeliti zemlju, ili pak potvrdu da su predali molbu za kolonizaciju. ${ }^{57}$ Najveće probleme pravile su odluke vlade u Sarajevu, što je uticalo da se preseljavanje iz Bosne vrši „,bez reda“".58 Uz odobrenje lokalnih organa, u konvojima iz ove jugoslovenske republike bilo je često više putnika nego odobrenih molbi. U depešama o transportima navođeni su pogrešni podaci. Stoga je u vojvođanska sela pristizalo više ljudi nego što je najavljeno, a dešavalo se da lokalne vlasti izveštaj o broju onih koji su krenuli na put ni ne pošalju. Da se nije radilo o sitnim propustima, pokazuju konvoji pristigli novembra 1945. iz Krupe i Ključa. U prvom je umesto najavljenih 18 porodica bilo čak 107, a u drugom je umesto 53 porodice stiglo $73 .{ }^{59}$ Čini se da su mesni organi u Bosni i Hercegovini razmišljali jedino kako da što više siromašnog i ratnim razaranjima pogođenog stanovništva pošalju u Vojvodinu, ne obazirući se preterano ni na propisane uslove za kolonizaciju niti na činjenicu da je ljude pokrenute sa svojih ognjišta trebalo smestiti i hraniti u vojvođanskim selima. Takav nehajan odnos je, sudeći po izveštajima koji se čuvaju u Arhivu Jugoslavije, dolazio do izražaja gotovo svakodnevno. Na meti kritika državnih vlasti posebno su se nalazili okružni narodni odbor Sarajevo, sreski odbor Zenica, Bosanski Petrovac i Visoko za koje je ocenjivano „da su učinili pogreške preko kojih se ne može preći“ “ ${ }^{60}$ Uprkos brojnim intervencijama Glavne komisije za naseljavanje i Ministarstva kolonizacije, ozbiljnijih pomaka $\mathrm{u}$ organizaciji rada lokalnih vlasti $\mathrm{u}$ Bosni nije bilo. Takvo lakomisleno postupanje, međutim, pravilo je probleme ne samo državnim organima već i ljudima koji su upućivani u Vojvodinu bez dozvole za kolonizaciju. Verujući da će u novoj naseobini sve dobiti, oni su u zavičaju prodavali sve što su imali upadajući tako u velike egzistencijalne probleme. ${ }^{61}$

\section{Kome će šta pripasti?}

Posle iscrpljujućeg putovanja, veliki broj kolonista se suočio sa teškim razočarenjem. Izobilja, o kome su danima pred polazak iz zavičaja slušali, nije bilo u napuštenim nemačkim selima. Uredba o osnivanju fondova stambenih $i$ poljoprivrednih zgrada, stambenog inventara i stoke, semena, hrane i pokućstva ${ }^{62}$

\footnotetext{
56 AJ, 97-1-6, Poverljivo 26/45, 21. 12. 1945.

57 AJ, 97-4-39, Br. 3701, 7. 12. 1945; Branko Petranović, Politička i ekonomska osnova narodne vlasti u Jugoslaviji za vreme obnove (Beograd: Institut za savremenu istoriju, 1969), 410.

58 AJ, 97-1-15, Br. 12/46, 4. 1. 1946.

59 AJ, 97-1-10, Br. 2626, 19. 11. 1945.

60 AJ, 97-3-36, Br. službeno od 26. 11. 1945.

${ }^{61}$ I. Dobrivojević Tomić, $n$. $d$. Videti i: AJ, 97-3-36, Br. službeno, 26. 11. 1945.

62 ,Уредба о оснивању фондова стамбених и пољопривредних зграда, стамбеног инвентара и стоке, семена, хране и покућства“, Службени лист, 21. 9. 1945.
} 
kojom je određeno raspolaganje konfiskovanom imovinom došla je sa zakašnjenjem. Do septembra 1945. veliki deo stvari bio je razvučen bez evidencije o tome koliko je čega bilo i ko je šta prisvojio. Štaviše, ni posle njenog donošenja nije bilo urađeno mnogo na evidentiranju i sređivanju podataka o pojedinim fondovima. Zemljišne knjige nisu redovno ažurirane, u pojedinim mestima nisu ni postojali katastarski operati, ${ }^{63}$ pa pitanje vlasništva nad zemljom i nad objektima nije bilo uvek do kraja jasno. Komisija za naseljavanje boraca stoga dugo nije raspolagala podacima Kolonizacionog fonda kuća, inventara i zemlje, ${ }^{64}$ što je otežavalo pravičnu raspodelu. Štaviše, zemlja predviđena za naseljavanje kolonista u jesen 1945. godine nije bila slobodna budući da se u Vojvodini nalazilo nekoliko desetina hiljada izbeglica sa Kosova, Metohije, iz Makedonije, Slavonije i Bosne i Hercegovine od kojih su mnogi angažovani na poljoprivrednim radovima. O koliko se ljudi radilo, teško je reći. Ministarstvo poljoprivrede i Glavni narodnooslobodilački odbor Vojvodine pokušali su da naprave približno tačnu evidenciju, ali se ispostavilo da je broj ovih samovoljnih kolonista varirao budući da su se mnogi vešto skrivali od svakog popisa. ${ }^{65}$

Po dolasku u Vojvodinu, kolonisti su zapošljavani na imanjima kao nadničari. Zasejane oranice koje je trebalo da dobiju ostale su, do sakupljanja letine, pod državnom upravom. Organizovani su specijalni poljoprivredni tečajevi, ${ }^{66}$ a setvene komisije su dobile zaduženje da u proleće 1946. godine pomognu novim vlasnicima da obrade svoja imanja ${ }^{67}$ Kako bi se premostilo vreme do prve žetve, naseljenicima je podeljena zemlja za bašte, veličine do $3 / 4$ jutra, koje su bile privremenog karaktera. ${ }^{68}$ Iako je Uredbom o sprovođenju naseljavanja boraca $u$ Vojvodini bilo predviđeno da kolonisti postanu vlasnici zemlje, ${ }^{69}$ „forsiranje“ stvaranja zadruga počelo je paralelno sa naseljavanju prvih kolonija. Uprkos željama kolonista da zemlju obrađuju individualno, rukovodstvo Glavne komisije za kolonizaciju iz Novog Sada je, i pored svih teškoća u podeli kuća, inventara i organizovanju ishrane, smatralo da je stvaranje zadruga „najvažnije“ ${ }^{70}$ Kako bi, makar formalno, stao na put ovakvoj praksi i sprečio eventualne izlive nezadovoljstva, Politbiro CK KPJ je februara 1946. doneo odluku ,da se ne izdaje uredba o radnim seljačkim zadrugama“ već da se one organizuju na dobrovoljnoj osnovi. ${ }^{71}$

Prema nedovoljno preciznim podacima, od Nemaca je konfiskacijom prikupljeno ukupno 58.335 stambenih zgrada, 37.294 poljoprivredne, 71 industrijska i 4.988 salaša. Sve te zgrade, međutim, nisu bile predviđene za kolonizaciju. Deo

\footnotetext{
${ }^{63}$ AJ, 97-9-61, Komisiji za agrarnu reformu i kolonizaciju, bez datuma.

${ }^{64}$ AJ, 97-3-36, Izveštaj o radu do 30. 9. 1945.

${ }^{65}$ I. Dobrivojević Tomić, $n$. $d$.

${ }^{66}$ N. Gaćeša, $n$. d., 338-339.

${ }^{67}$ AJ, 97-1-11, Nezavedeno, septembar 1945.

${ }^{68}$ AJ, 97-14-93, Glavnoj komisiji za naseljavanje boraca, bez datuma.

69 „Уредба о спровођењу насељавања бораца у Војводини“, Службени лист ДФЈ, бр. 72, 1945.

70 AJ, 50-89-188, Izvještaj Kontrolne komisije pri Predsedništvu FNRJ od 18. 1. 1946. Videti i: М. Бошковић и М. Шутић, $н$. д., 178, 182.

${ }^{71}$ Branko Petranović (prir.), Zapisnici sa sednica Politbiroa Centralnog komiteta KPJ (11. 6. 1945 - 7. 7. 1948) (Beograd: Arhiv Jugoslavije, Službeni list SRJ, 1995), 136.
} 
je ustupljen na korišćenje različitim državnim ustanovama i masovnim organizacijama, a neznatan broj vraćen je ranijim vlasnicima. Do jeseni 1945. godine, odnosno do dolaska prvih kolonista, meštani vojvođanskih sela su se samovoljno uselili u mnoge prazne kuće i prisvojili pokućstvo koje je ostalo. Jedan deo ove imovine razvučen je i u borbama za oslobođenje. Nešto su uzeli borci Crvene armije, deo boljeg inventara poklonjen je partizanskim oficirima, dok je deo luksuznih stvari prodat narodnim magazinima. ${ }^{72} \mathrm{Uz}$ to, veliki broj zgrada teško je postradao $\mathrm{u}$ ratnim operacijama i one nisu mogle biti naseljene bez većih popravki, dok je jedan deo kuća za zemljoradnike bio nepodesan budući da se nalazio u varošima. ${ }^{73}$

Raspodelu kuća, stoke i inventara vršile su mesne komisije u čiji su sastav ušli i predstavnici kolonista. ${ }^{74}$ Neuhodanost i samovolja njihovih članova prouzrokovala je socijalne nepravde koje je kasnije bilo nemoguće ispraviti. Pristrasnost komisija bila je očigledna, pa su one, zbog svog postupanja, u potpunosti ,izgubile autoritet kod naseljenika“‘. ${ }^{75} \mathrm{U}$ želji da svoju porodicu što bolje obezbede, ništa pravičnije nisu postupali ni kolonisti ako su bili u prilici da sami biraju kuće. „Pravo jačega“ prouzrokovalo je stalne čarke i svađe, ${ }^{76}$ pa je u takvoj atmosferi bilo gotovo nemoguće izvršiti pravednu podelu imovine. Otvoreno je priznavano da čak i one komisije ,koje su umele i htele“ da u potpunosti primene sve kriterijume za raspodelu ,nisu bile u stanju da to učine“. Ni u jednoj koloniji ,autoritet vlasti i samih komisija nije mogao da obezbedi ravnomernu raspodelu“ dobrih i slabih kuća od početka naseljavanja. Stoga su porodice koje su došle nešto kasnije, a naročito tokom 1946. godine morale da se zadovolje trošnijim zgradama. $^{77}$ Štaviše, u svojevrsnoj anarhiji koja je vladala u kolonijama, nije bilo moguće ni sprečiti uništavanje i ruiniranje nenaseljenih kuća. ${ }^{78}$ Izgovarajući se potrebom da svoj stambeni prostor urede, kolonisti su iz praznih zgrada odnosili sve šta im je bilo potrebno - skidali su prozore i vrata, čupali podove i vadili cigle iz zidova. ${ }^{79} \mathrm{U}$ vremenima oskudice činilo se da je sve dozvoljeno kako bi se preživelo. Solidarnost i osećaj za pravdu su se gubili, pa niko nije razmišljao o šteti koju pravi porodici koja će se u tako ruiniranu kuću useliti.

Uprava narodnih dobara je raspolagala sa nedovoljno pokućstva, tekstila $\mathrm{i}$ stoke, a i ono malo nameštaja što je sačuvano od razvlačenja čuvano je u vlažnim i nedovoljno podesnim magacinima. ${ }^{80} \mathrm{O}$ razmerama posleratnog siromaštva najbolje svedoči plan raspodele pokretne imovine koji je izradila Glavna poljopri-

\footnotetext{
${ }^{72}$ AJ, 97-9-61, Komisiji za agrarnu reformu i kolonizaciju, bez datuma; Videti i: B. Petranović, Političke i pravne prilike..., 50-51; Branko Petranović i Momčilo Zečević, Agonija dve Jugoslavije (Beograd: Zaslon, 1991), 296.

${ }^{73}$ AJ, 97-12-79, Pov. br. 19, 24. 2. 1947.

74 „Министар Сретен Вукосављевић о колонизацији у Војводини“, Политика, 8. 9. 1945.

${ }^{75}$ AJ, 97-3-36, Izveštaj o radu sa terena od 30. 9. 1945.

${ }^{76}$ AJ, 97-9-61, Izveštaj o radu i životu kolonista u Francestalu; AJ, 97-14-89, Izveštaj iz Banatskog Velikog Sela, 6. 3. 1948.

${ }^{77}$ AJ, 97-12-81, Br. 4591/47, 28. 5. 1947.

${ }^{78}$ AJ, 97-14-89, Izveštaj od 9. 2. 1948.

${ }^{79}$ AJ, 97-14-89, Izveštaj iz Banatskog Velikog Sela.

${ }^{80}$ AJ, 97-5-34, Zapisnik saslušanja Radišić Milana iz sela Mramorka od 16. 1. 1946.
} 
vredna komisija za Vojvodinu avgusta 1945. godine. Prema ovom ključu, svaka porodica, bez obzira na broj članova, trebalo je da dobije dva kreveta, jednu slamaricu, četiri jastuka, četiri stolice, jednu šerpu, jedan lonac, jednu kašiku ili jedan nož, jednu viljušku i tri kokoške. ${ }^{81}$ Ukupan stočni fond iznosio je 14.000 krava i 7.000 junadi, ${ }^{82}$ pa su po tri porodice bile prinuđene da dele kravu, što je naročito teško padalo doseljenicima iz stočarskih krajeva. ${ }^{83}$ Kako su kuće dodeljivane prema broju članova prijavljenih za kolonizaciju, a ne broju stvarno doseljenih, nepravde pri raspodeli predstavljale su svakodnevnu pojavu. Deljenje porodica i delimično odustajanje od kolonizacije izazivali su nezadovoljstvo kod onih koji su se kasnije doselili, jer su za njih, bez obzira na broj članova, ostajale manje i lošije kuće. ${ }^{84}$ Nedostatak osnovnih stvari neophodnih za život budio je i ono najgore u ljudima. Pojedinci su ,sa pištoljem u ruci“ otimali stvari pri raspodeli ${ }^{85}$ ili pak tužakali jedni druge i za najsitnije nepravde. Komšijski nameštaj je uvek delovao lepše i bolje, pa su ,revnosni“" kolonisti dostavljali čitave spiskove u kojim kućama se nalaze „kompletne spavaće sobe od limunovog i orahovog drveta“ 86

Međutim, uprkos ponekom banalnom slučaju, ${ }^{87}$ nesklad u imovinskom stanju doseljenika, prouzrokovan podelom pokretne i nepokretne imovine, bio je očigledan. Splet srećnih okolnosti, boračke zasluge ili protekcija predstavljali su neke od faktora koji su uticali na budući život kolonista. Pojedine porodice su naseljavane u kuće sa električnim instalacijama, dok su se druge morale nastaniti u objekte u kojima drugog poda, osim zemljanog, nije bilo. Lične veze i poznanstva sa članovima komisija igrale su, izgleda, izvesnu ulogu. Kolonisti iz Ravnog smatrali su da su pri raspodeli imovine učinjene nepravde jer su ,u komisiji bili Crnogorci“ koji su dodeljivali ,bašte i bolje kuće Crnogorcima bez obzira da li su drugi kolonisti imali veće i opravdanije razloge i potrebe“. Višečlane porodice su smeštane u male i nepodesne kuće dok su one manje imale višak stambenog prostora koji su izdavale. ${ }^{88}$ O socijalno ugroženim licima - invalidima, udovicama, bolesnim borcima i njihovim potrebama uglavnom se nije vodilo računa. Njihovi ,opravdani zahtevi““ ili nisu uzimani u razmatranje ili su, naročito kod udovica, rešavani na njihovu štetu. ${ }^{89}$

${ }^{81}$ AJ, 97-11-73, Objašnjenje o raspodeli fondova kojima je rukovodila Glavna poljoprivredna komisija za Vojvodinu.

${ }^{82}$ AJ, 97-2-21, Izveštaj Privredno-tehničkog odeljenja Saveznog ministarstva kolonizacije, 31.12.1945.

${ }^{83}$ AJ, 97-11-73, Objašnjenje o raspodeli fondova kojima je rukovodila Glavna poljoprivredna komisija za Vojvodinu; Milorad Vasović, Najnovije naseljavanje Crnogoraca u nekim bačkim selima (Novi Sad: Matica srpska, 1959), 27.

${ }^{84}$ AJ, 97-14-88, Problem kolonista koloniziranih u Vojvodini sa teritorije Srbije i Kosmeta, 8. 2. 1947.

${ }^{85}$ AJ, 97-2-21, Beleške sa puta u Bačku (Moša Pijade, Jovan Veselinov i Maksim Goranović).

${ }^{86}$ AJ, 97-11-71, Dostavljaju se podaci koje je Komisiji za agrarnu reformu i kolonizaciju dao slepi invalid Ratibor Jovanović o zloupotrebi i upropašćavanju državne imovine i nepravilnom rukovanju sa njom u Vršcu i Beloj Crkvi, 38. 7. 1946.

${ }^{87} \mathrm{U}$ Arhivu Jugoslavije se čuva dokument u kome se može pročitati i da je mesna komisija u Čonoplji „nepravilno“ delila nameštaj i tekstil pa je tako Miloš Savić dobio dva šešira, a Dušan Stokrop nijedan, pa ga je morao kupiti od Miloša. AJ, 97-11-71, Izjava Đure Basare i Stokrop Dušana u Komisiji za agrarnu reformu i kolonizaciju, 19. 3. 1946.

${ }^{88}$ I. Dobrivojević Tomić, $n$. $d$.

${ }^{89}$ AJ, 97-14-89, Izveštaj od 9. 2. 1948. 
Ovakvi postupci izazivali su ogorčenje i revolt, a najuporniji su dolazili u Beograd da se žale. ${ }^{90}$ Sve pritužbe na rad mesnih komisija ličile su jedna na drugu, a zajedničko im je bilo da se bez poznanstva ${ }^{91}$ ili obećanja kakve usluge i davanja mita, pristojna kuća ne može dobiti. ${ }^{92}$ Kolonisti su izjavljivali da članovi komisija za sebe biraju najbolje zgrade, ,pune nameštaja i posuđa“, 93 u kojima pojedine prostorije daju pod kiriju nekolonistima. ${ }^{94}$ Kako je u svakom selu bilo desetak porodica nezadovoljnih kućama, otvoreno demonstriranje nezadovoljstva predstavljalo je svakodnevnu pojavu. Prednjačili su niži oficiri i nosioci Partizanske spomenice koji su pretili da će se vratiti u stari kraj ili najavljivali da će se obratiti nekom višem rukovodiocu ukoliko se njihovim zahtevima ne izađe u susret. ${ }^{95}$

Kolonisti su se teško mirili sa činjenicom da je u nekim mestima predviđenim za naseljavanje za borce iz Bosne i Hercegovine, ponekad bilo i četiripet puta manje slobodnih kuća nego porodica. ${ }^{96}$ Poseban revolt je, stoga, izazivalo smeštanje više familija u jedan dom. „U Vojvodinu je došla svaka familija sa ubeđenjem da će ovde dobiti punu kuću i da će odmah biti gospodari kuće“, moglo se pročitati u jednom od izveštaja Glavne komisije iz januara 1946. godine. Međutim, ,kad uvide da ne samo da je kuća prazna, nego i da nisu gospodari kuće, dolazi do razočarenja i nezadovoljstva““.97 Karakterističan je primer kolonista pristiglih u Krnjaju koji osam dana nisu želeli da izađu iz vagona kada su shvatili da svakoj od porodica ne sleduje kuća. Razočarenje nije bilo moguće suzbiti ni obećanjima da će autokolonisti biti iseljeni niti uveravanjem da će se vrlo brzo pristupiti opravci i izgradnji novih zgrada. Izneverena očekivanja pretvarala su se u nezadovoljstvo i otvoreno negodovanje. Čak i ako bi mesne komisije popustile pod pritiskom, neke od doseljenika je bilo teško zadovoljiti. Dešavalo se da pojedinci po ceo dan biraju kuću i opet ne mogu naći neku koja bi odgovarala njihovim zamislima i očekivanjima. Mnogo svađe i prepirke bilo je i oko pokućstva i tekstila, a deoba kuća je mogla trajati nedeljama, što je uticalo da kolonisti ,zaborave na sav život i rad“".98

Koliko su sva ova nezadovoljstva bila opravdana, na osnovu raspoloživih izvora teško je reći. Među nezadovoljnicima bilo je i onih koji su gledali da se u datom trenutku više okoriste, uz argument da u porodici ima nekoliko sinova koji su pred ženidbom, te da im zato treba dati više kuća. ${ }^{99}$ Nesklad između prevelikih

\footnotetext{
${ }^{90}$ AJ, 97- 3-28, Nezavedeno od 29. 12. 1945; AJ, 97-11-71, Više žalbi.

${ }^{91}$ AJ, 97-11-71, Zapisnik rađen u Komisiji za agrarnu reformu i kolonizaciju pri vladi FNRJ u Beogradu dana 19. 9. 1946.

92 AJ, 97-11-71, Rađeno u Komisiji za agrarnu reformu i kolonizaciju pri vladi FNRJ u Beogradu dana 6. 8. 1946.

${ }^{93}$ AJ, 97-11-71, Rađeno u Komisiji za agrarnu reformu i kolonizaciju pri vladi FNRJ u Beogradu dana 19. 7. 1946.

${ }^{94}$ AJ, 97-11-71; Rađeno u Komisiji za agrarnu reformu i kolonizaciju pri vladi FNRJ u Beogradu dana 10. 7. 1946.

${ }^{95}$ I. Dobrivojević Tomić, $n$. $d$.

${ }^{96}$ AJ, 97-3-36, Br. 3158, 27. 11. 1945; N. Gaćeša, n. d., 332.

${ }_{97}$ AJ, 97-11-75, Br. 61, 4. 1. 1946.

${ }^{98}$ I. Dobrivojević Tomić, $n$. $d$.

${ }^{99}$ AJ, 97-9-61, Izveštaj o radu i životu kolonista u Francestalu.
} 
očekivanja i ekonomskih prilika u Vojvodini, kao i nepoklapanje osećaja kolonista za (socijalnu) pravdu i kriterijuma vlasti koji su trebali da garantuju pravičnu raspodelu stvorili su atmosferu u kojoj je mnogo demobilisanih boraca smatralo da su uskraćeni za neka prava koja im po zakonu pripadaju. Dok su kolonisti verovali da broj članova porodice treba da predstavlja jedan od osnovnih kriterijuma pri dodeli imovine, državni organi su isticali da oni naseljenici koji su imali naročite zasluge u ratu kao i one porodice koje nisu sposobne za samostalno privređivanje moraju biti favorizovane u odnosu na velike, ekonomski sposobne familije ,koje su u stanju da sebi naprave i kuću i štalu i sve drugo što im bude potrebno“. 100 Bahatost lokalnih vlasti, a naročito oficira koji su u Sivcu upadali u kolonističke kuće, pretresali ih i odnosili nameštaj koji im se dopadao lakonski objašnjavajući da se radi o ,švapskim stvarima“, izazivala je kod novih doseljenika osećanje nemoći i očaja. ${ }^{101}$ Glavna komisija za naseljavanje boraca, iako je na to imala pravo, nikad nije pristupila detaljnoj reviziji kuća i zemljišta. ${ }^{102}$ Ovako veliki posao u mnogim mestima nije bilo moguće ni izvršiti, budući da su gotovo sve kuće građene od slabog materijala - čerpiča i naboja. ${ }^{103}$ Nova raspodela imovine vršena je samo u onim selima u kojima su ,nepravde po obimu i drastičnosti bile velike“. ${ }^{04}$ Međutim, jednom učinjene greške bilo je teško ispraviti bez pravljenja novih. U nedostatku preciznih kriterijuma, dešavalo se da se i kockom odlučuje koja će porodica ostati, a koja će se iseliti iz neke kuće, ${ }^{105}$ pa su preseljenja, ako su u većem obimu sprovođena, izazivala ,prilično uznemirenje“ među kolonistima. ${ }^{106}$

\section{Razočarenje}

Velika želja za preseljenjem i verovanje da kolonizacija predstavlja trajno izbavljenje iz siromaštva ponekad su, paradoksalno, otežavali integraciju u novu sredinu. Nezadovoljstvo koje se kod dela naseljenika javljalo na samom početku, prilikom dugog i iscrpljujućeg putovanja, raslo je dolaskom u Vojvodinu i postepenim saznavanjem da i u novom zavičaju vladaju oskudica, siromaštvo i glad. Snovi o jednakosti i socijalnoj pravdi nestajali su prilikom dodele zemlje, kuća i poljoprivrednog i drugog inventara. Kolonisti su se pitali zašto „mnoge korisne i potrebne stvari" stoje i trunu po magazinima narodnih dobara i kako je moguće da iz sela u kojima oni ,,bez najnužnijih stvari“ žive izlaze kamioni ,puni skupocenog nameštaja“. ${ }^{107} \mathrm{Ni}$ molbe ni žalbe vlastima nisu mnogo pomagale. Dovoljno nameštaja, posteljine, tekstila i pokućstva za sve naseljenike nije bilo. O stepenu očaja onih

\footnotetext{
${ }^{100} \mathrm{AJ}, 97-12-81$, Br. 4591, 28. 5. 1947.

${ }^{101}$ AJ, 50-89-188, Izveštaj Kontrolne komisije pri Predsedništvu vlade FNRJ, 18. 1. 1946.

102 AJ, 97-12-81, Br. 4591, 28. 5. 1947.

${ }^{103}$ AJ, 97-14-89, Izveštaj iz Banatskog Velikog Sela, 6. 3. 1948.

${ }^{104}$ AJ, 97-12-81, Br. 4591, 28. 5. 1947.

105 AJ, 97-11-71, Ostojić Vuksan iz Novog Sivca, žalba zbog iseljavanja iz dodeljene mu kuće kao kolonisti putem kocke, 18. 12. 1946.

106 AJ, 97-14-89, Izveštaj od 9. 2. 1948.

107 AJ, 50-89-188, Izveštaj Kontrolne komisije pri Predsedništvu vlade FNRJ, 18. 1. 1946. Videti i: M. Vasović, $n$. d., 16.
} 
koji nisu uspeli da sebe i svoju porodicu obezbede svedoče žalbe poslate Ministarstvu i Glavnoj komisiji za naseljavanje boraca. Jedna od potresnijih bila je ona koju su poslali kolonisti iz Saltura (kikindski srez): „Nemamo kreveta za spavanje već ležimo na zemlji. U našim sobama su polupani prozori i vrata nemamo. Nemamo šporeta za kuvanje jela pošto su sve bolje kuće i nameštaj i pokućstvo uzeli oni kolonisti koji su došli prošle jeseni a mi 50 porodica došli smo u prazne najslabije kuće. Molili smo ovdašnji odbor da nam se gornji navodi udovolje i do danas nema ništa. Govore nam: Ako vam se ne dopada, hajdete nazad u Bosnu. Zima dolazi, a mi drva nemamo, odeće i obuće nemamo, a nemamo za čega ni kupiti““. ${ }^{108}$

Nenavikli na nove uslove života, više gladni nego siti, kolonisti su se dovijali kako su znali i umeli ne bi li nekako savladali oskudicu i sačekali setvu 1946. godine. Ogreva u većini sela nije bilo, pa su kolonisti, da bi preživeli oštru vojvođansku zimu, sekli drvorede po ulicama i ložili drvenariju iz kuća, prouzrokujući tako još veću štetu. ${ }^{109}$ Već u decembru 1945. nijedna uprava narodnih dobara ,nije bila u stanju“ da kolonistima izda hranu prema propisanoj tablici. ${ }^{110}$ Deljeno je samo kukuruzno i pšenično brašno, ${ }^{111}$ dok su u pogledu snabdevanja drugim proizvodima kolonisti bili izjednačeni sa ostalim stanovništvom. ${ }^{112}$ Nenavikli na tipična vojvođanska jela, kolonisti su mnoge namirnice poput geršle i makarona odbijali da uzmu, pravdajući se da ,na njih nisu naučili““. ${ }^{113}$ U zamenu su tražili pasulj koga nije bilo, baš kao ni masti, ulja, suvog mesa i slanine. Ovakva neredovna i nezadovoljavajuća ishrana izazivala je ,veliko negodovanje ${ }^{\text {(114 }}$ i primoravala koloniste da svoj novac, ako su ga uopšte i imali, troše na crnoj berzi. ${ }^{115}$ Razmera problema su bile svesne i vlasti. Konstatovano je, stoga, da se, ukoliko se ishrana ne popravi, do proleća može desiti da „većina naroda“ bude nesposobna za fizičke poslove. ${ }^{116}$ Međutim, na opšte siromaštvo naseljenika nisu uticale samo teške ekonomske prilike i ratna razaranja. Loša organizacija snabdevanja i slaba koordinacija rada lokalnih vlasti dovodile su do paradoksalnih situacija, pa su neka sela imala nekih prehrambenih proizvoda u izobilju, dok je u drugim vladala nestašica. ${ }^{117}$ Pojedine namirnice stajale su u magacinima po mesec i više dana jer se nije znalo ko je nadležan da ih podeli. ${ }^{118}$ Ništa bolje organizovana nije bila ni deoba Unrine robe koja je gomilana u magacinu u Bačkoj Palanci iako se u brojnim kolonističkim selima osećala ,izuzetno velika golotinja“. ${ }^{119}$

\footnotetext{
108 AJ, 97-11-71, Ministarstvu i Komisiji za kolonizaciju boraca.

${ }^{109}$ AJ, 97-5-43, Br. 3321, 2. 1. 1946.

$110 \mathrm{AJ}, 97-5-43, \mathrm{Br} .3321,2.1$. 1946; „Проблеми и садашње стање колонизације у Војводини“, Политика, 1. 6. 1946.

${ }^{111}$ AJ, 97-11-75, Br. 6170, 15. 3. 1946.

112 AJ, 97-11-73, Br. 7566, 21. 5. 1946.

${ }_{113}$ AJ, 97-9-60, Izveštaj Glavne komisije za naseljavanje boraca u Vojvodini, 12. 4. 1946.

${ }^{114}$ AJ, 97-11-73, Br. 7566, 21. 5. 1946.

115 AJ, 97-5-43, Br. 3321, 2. 1. 1946; B. Petranović, Političke i pravne prilike..., 410.

${ }^{116}$ AJ, fond 507, CK SKJ, V, k - IV / 59, Izveštaj Dušana Asanovića Centralnom komitetu KPJ. Organizacijsko-instruktorskom odeljenju, 13. 1. 1946.

117 AJ, 97-5-43, Br. 3321, 2. 1. 1946.

118 AJ, 97-9-61, Izveštaj sa terena kolonista naseljenih iz Crne Gore, 6. 4. 1946.

${ }^{119}$ AJ, 50-89-188, Izveštaj Kontrolne komisije pri Predsedništvu vlade FNRJ, 18. 1. 1946.
} 
Članovi Glavne komisije za naseljavanje boraca ocenjivali su da uključivanje kolonista u poljoprivredu ide teško budući da im „o njihovim obavezama spram društva i države u novom kraju“ ništa nije govoreno. Lokalni organi u Bosni su kolonizaciju predstavljali kao „odmor“ i ,zimovanje“, ${ }^{120}$ pa su Hercegovci posebno negodovali kad im je saopšteno da je rad obavezan. ${ }^{121}$ Međutim, nisu samo kolonisti imali velika nadanja. Očekivanja vlasti da će se sitnoposednici pridošli iz neplodnih i brdskih krajeva zemlje privremeno zaposliti u industriji ili obrađivati zemlju za nadoknadu do prve setve bila su nerealna. Kolonisti raspoređeni po fabrikama masovno su napuštali posao, ${ }^{122}$ njive i bašte ostajale su neobrane, ${ }^{123}$ a stoka nenamirena. ${ }^{124} \mathrm{U}$ prvim mesecima po naseljavanju pojedinci su od Nemaca logoraša očekivali da za njih rade, ${ }^{125}$ a vreme su provodili „odajući po selu“ i diskutujući šta je ko dobio. ${ }^{126}$ Vlasti su slabo radno angažovanje objašnjavale činjenicom da, usled organizovanog snabdevanja preko mesnog odbora, naseljenici o hrani ne moraju razmišljati. ${ }^{127}$ Kritikujući ,besposličenje ${ }^{\text {“128 }}$ i lenjost, vlasti su, čini se, zaboravljale da su na radni elan velikog dela ljudi uticali i realni životni problemi sa kojima su se suočavali u novoj sredini. Rat je prošao, ali njegove psihološke posledice bile su vidljive kod mnogih. Invalidi i demobilisani borci ,pravili su nerede“ na priredbama i konferencijama pucajući iz pištolja i plašeći ljude. Opijanja, ${ }^{129}$ krađe $^{130}$ i prepirke oko stambenih zgrada i inventara postajali su svakodnevica u kolonističkim selima. Neprekidne žalbe na dodeljeni smeštaj i politika zamene kuća izazivali su nespokoj. Na osećaj privremenosti nadovezivale su se i nedovoljno razvijene higijenske navike ponete iz starog kraja, pa su u početku ulice i domovi „bile nečisti i zapušteni“. ${ }^{131}$

Već u decembru 1945. bilo je jasno da se „najveći broj kolonista razočarao““ ${ }^{132}$ Izneverena očekivanja ali i svojevrsni kulturni šok uticao je na mnoge da počnu da razmišljaju o povratku u stari kraj. Novu selidbu, međutim, otežavali su republički propisi o agrarnoj reformi i kolonizaciji koji su se razlikovali od republike do republike. Najmanje briga imali su kolonisti iz Crne Gore budući da imanja koja su ostavili nisu došla pod udar agrarne reforme. Prema bosanskom

${ }^{120}$ AJ, 97-2-19, Zapisnik sa sastanka delegata rukovodilaca kolonizacije federalnih jedinica koji je održan u Ministarstvu kolonizacije FNRJ u Beogradu dana 15. 12. 1945.

${ }^{121}$ I. Dobrivojević Tomić, $n$. $d$.

${ }_{122}$ AJ, 97-2-21, Beleške sa puta u Bačku (M. Pijade, J. Veselinov i M. Goranović).

${ }^{123}$ AJ, 97-9-60, Br. 3666, 27. 3. 1946; AJ, 97-9-61, Izveštaj o životu i radu kolonista u Francestalu - Zemun, bez datuma, 1946.

${ }^{124}$ AJ, 97-9-60, Br. 3666, 27. 3. 1946.

${ }^{125}$ AJ, 97-2-19, Zapisnik sa sastanka delegata rukovodilaca kolonizacije federalnih jedinica koji je održan u Ministarstvu kolonizacije FNRJ u Beogradu dana 15. 12. 1945.

126 AJ, 97-9-61, Izveštaj o životu i radu kolonista u Francestalu - Zemun, bez datuma, 1946.

${ }^{127}$ AJ, 97-2-21, Beleške sa puta u Bačku (M. Pijade, J. Veselinov i M. Goranović).

${ }^{128}$ AJ, 97-2-25, Izveštaj iz Šupljaje.

${ }^{129}$ AJ, 97-2-21, Beleške sa puta u Bačku (M. Pijade, J. Veselinov i M. Goranović).

${ }^{130}$ AJ, 97-12-79, Izveštaj od 27. 12. 1946.

131 V. Đurić, $n$. d., 14.

132 AJ, 97-2-19, Zapisnik sa sastanka delegata rukovodilaca kolonizacije federalnih jedinica koji je održan u Ministarstvu kolonizacije FNRJ u Beogradu dana 15. 12. 1945. 
zakonu u zemljišni fond je trebalo da uđu i posedi kolonista ,,ukoliko se u roku od dve godine" ne vrate u zavičaj. Istu odredbu, bez prelaznog roka za prilagođavanje, predvideli su hrvatski, makedonski i srpski zakon, što je povratničke porodice dovodilo u težak položaj. ${ }^{133}$ Najlakše su se na povratak odlučivale porodice boljeg imovinskog stanja, to jest oni koji su se imali gde vratiti, ${ }^{134}$ ali je bilo i siromašnih kolonista koji su napuštali Vojvodinu. ${ }^{135}$ Motivi za povratak bili su različiti: oskudna ishrana, osećaj da im je naneta nepravda pri raspodeli imovine, ${ }^{136}$ širenje skorbuta i stomačnih bolesti, velika smrtnost dece, ${ }^{137}$ nenaviknutost na klimu i život u ravnici, ${ }^{138}$ nezadovoljstvo razrezanim otkupnim obavezama i privređivanjem u zadruzi. ${ }^{139}$ Bilo je i onih koji očigledan razlog za povratak nisu imali, pa su vlasti smatrale da se vraćaju ,prosto iz inata“. ${ }^{140}$

Stepen prilagodljivosti i spremnost na integraciju razlikovao se od čoveka do čoveka, pa opšteg konsenzusa po pitanju mesta življenja često nije bilo ni u okviru jedne porodice. Nenaviknutost na život u ravnici, tuga za zavičajem, sklapanje brakova, zapošljavanje $\mathrm{u}$ industrijskim preduzećima i prihvatanje novih kulturnih obrazaca, naročito kod mlađih ljudi, predstavljali su samo neke od faktora koji su uslovili raspadanje velikih porodica i njihovu deobu na više inokosnih. Kod onih koji su se odlučivali za povratak, ni materijalni interes nije bio zanemarljiv. Povratak dela nekad velike porodice omogućavao je njenim članovima da zadrže oba imanja i obezbede sebi pristojniju egzistenciju. ${ }^{141}$ Uprkos svemu, odluku o povratku nije bilo lako doneti, pa su sve do početka 50-ih godina trajale migracije kolonista. ${ }^{142}$ Jednom iščupani iz svoje sredine, rastrzani između novih i starih naseobina u kojima su ostavili rođake i komšije, pojedinci su se vraćali i odlazili i po nekoliko puta. ${ }^{143}$

\section{U ravnici se ipak (ne)može živeti}

Koliko se promenio svakodnevni život kolonista dolaskom i Vojvodinu i do koje mere je tu promenu bilo teško prihvatiti, najbolje ilustruje podatak da se do marta 1946. iz gotovo svakog sela iselilo po nekoliko porodica. ${ }^{144}$ Među povratnicima bilo je najviše doseljenika iz Bosne i Hercegovine, što je i razumljivo s obzirom na to da je ova republika imala najveću kvotu za kolonizaciju. ${ }^{145} \mathrm{U}$ nekim naseljima povratak u

\footnotetext{
${ }^{133}$ AJ, 97-1-12; AJ, 97-5-43, Br. 666, 29. 1. 1946; AJ, 97-9-65, Br. 24242, 5. 7. 1946; AJ, 97-543, Br. 666, 29. 1. 1946.

${ }^{134}$ AJ, 97-9-60, Izveštaj o radu glavne Komisije za naseljavanje boraca - Novi Sad, 30. 12. 1946; AJ, 50-89-188, Izveštaj, novembar 1947.

135 AJ, 97-9-60, Dekolonizacija boračkih porodica, 9. 3. 1946.

${ }^{136}$ Isto.

${ }^{137}$ AJ, 97-9-61, Br. 7757, 5. 8. 1946.

${ }^{138}$ AJ, 97-14-88, Br. 6084, 12. 11. 1947.

139 AJ, 50-89-188, Izveštaj Dukić Dušana i dr. Komisiji za agrarnu reformu i kolonizaciju pri vladi FNRJ, 13. 10. 1947.

${ }_{140}$ AJ, 97-9-60, Br. 3666, 27. 3. 1946.

${ }^{141}$ AJ, 97-14-88, Br. 18539/47, 13. 10. 1947; V. Đurić, n. d., 15.

${ }^{142}$ V. Đurić, $n . d ., 14-15$.

${ }^{143}$ Isto, 51; M. Vasović, $n$. d., 30.

${ }^{144}$ AJ, 97-11-75, Br. 6170, 15. 3. 1946.

${ }^{145}$ AJ, 97-9-60, Dekolonizacija boračkih porodica, 9. 3. 1946.
} 
stari kraj bio je relativno masovan, pre svega tokom 1946. godine. Iz Bačkog Dobrog Polja se tako vratilo 125 porodica, iz Šupljaje 104, a iz Prigrevice 103. ${ }^{146}$ Uglavnom su napuštane kolonije u kojima su uslovi života bili najteži - sela slabije uređena, kuće trošne i oronule, a inventar oskudan. ${ }^{147}$ Raspoloženje za povratak je u narednim mesecima postajalo sve izraženije, ${ }^{148}$ uprkos nastojanjima vlasti ,da se ni jedna kolonistička porodica ne vrati““. ${ }^{149}$ Pokušaji da se doseljenici ubede da ostanu svodili su se uglavnom na materijalno uslovljavanje. Nisu im izdavane karte za povratak, insistirano je da plate obradu zemlje i hranu koju su uzimali na kredit i da predaju sav inventar koji su dobili. ${ }^{150}$ Pokazalo se, međutim, da ovakva politika nije davala očekivane rezultate. Želja za povratkom nadjačavala je i materijalni interes, pa se u stari kraj vratilo oko $9 \%$ doseljenih kolonista, ${ }^{151}$ odnosno ukupno 3.882 porodice. $^{152}$ Pojedinci su kupovali karte za put od svog novca, ostavljajući sve ono što su kao kolonisti dobili, i odlazili bez znanja i odobrenja Glavne komisije za naseljavanje. ${ }^{153}$ Drugi su se, pak, u želji da nešto od dobijenog inventara zadrže, prosto iskradali iz kolonija i odlazili na udaljene železničke stanice ne bi li na taj način sprečili oduzimanje pokretne imovine koja im je dodeljena. ${ }^{154}$ Oni najogorčeniji revoltirano su pretili vlastima da će sve stvari koje su dobili uništiti ako neko pokuša da im ih oduzme. ${ }^{155}$

Kolonisti koji su ostali nisu se ni brzo ni lako prilagodili. Novi način življenja bilo je teško prihvatiti, pa su doseljenici gledali da svoje domaćinstvo urede nalik onome u zavičaju. Keramičke sobne peći uklanjane su iz stanova, a ormani prepravljani u sanduke za odeću. ${ }^{156}$ Nesnalaženja je bilo i sa korišćenjem električnih i sanitarnih uređaja, ${ }^{157}$ ali i poljoprivrednih mašina i alata. ${ }^{158}$ Privikavanje na nov način obrade zemlje, dublje oranje, nove kulture i štalsko stočarstvo naročito je teško padalo doseljenicima iz planinskih regiona koji su kasnije u šali pričali da u prve dve godine ,ni jedan poljski rad nisu mogli da urade kako treba“. ${ }^{159}$ Puno problema je

${ }^{146}$ N. Gaćeša, $n$. $d$., 355.

${ }^{147}$ AJ, 97-9-60, Br. 2665, 12. 3. 1946.

148 AJ, 97-14-88, Br. 8100, 10. 11. 1947.

${ }^{149}$ AJ, 97-14-88, Br. 7834, 7. 9. 1947.

${ }^{150}$ AJ, 97-9-60, Izveštaj o radu glavne Komisije za naseljavanje boraca - Novi Sad, 30. 12. 1946.

${ }^{151}$ Бранислав Ђурђев, Послератно насељавање Војводине. Методи и резултати демографске анализе насељаваља Војводине у периоду 1945-1981 (Нови Сад: Матица српска, 1995), 66.

${ }^{152}$ N. Gaćeša, $n$. d., 255.

153 AJ, 97-9-60, Stanje i problemi kolonizacije, 31. 12. 1946.

${ }_{154}$ AJ, 97-12-79, Nezavedeno, 27. 12. 1946.

155 AJ, 97-11-71, Rađeno u Otseku za preseljavanje Komisije za agrarnu reformu i kolonizaciju pri vladi FNRJ dana 7. 11. 1946.

156 Десанка Николић, „Преображаји - етнолошки поглед“, у: Бачко Добро Поље - горштаии у равници, уредник Обрен Благојевић (Београд: Етнографски институт САНУ, 1979), 238-241.

${ }^{157}$ Vinko Jeržabek, „Kolonizacija u Vršcu“, Sociologija sela, br. 9, (1965), 38; „Горштаци у равној земљи. Херцеговци из околине Стоца у Банатском селу Катарина“, Политика, 26. 9. 1945.

${ }^{158}$ Vesna Katić, ,Promene društvenog i običajnog života kolonista iz Bosanske Krajine u vojvođanskim selima“, (magistarski rad, Univerzitet u Beogradu, Filozofski fakultet, Odeljenje za etnologiju, 1985), 22; Jovan Trifunovski, O posleratnom naseljavanju stanovništva iz NR Makedonije u tri banatska naselja - Jabuka, Kačarevo i Glogonj (Novi Sad: Matica srpska, 1958), 19.

159 Јован Трифуновски, Послератно насељавање становништва у Руми, Хртковиима и Никинциима (Нови Сад: Матица српска, 1958), 66-67. 
bilo i u odnosima sa lokalnim stanovništvom koje ih je smatralo „,balastom“. 160 Štaviše, i pojedini mesni narodni odbori su se ,gotovo neprijateljski prema njima odnosili“" odbijajući da Glavnoj komisiji dostave spisak napuštenih nemačkih kuća. ${ }^{161}$ Podvojenost stanovništva nije bilo jednostavno prevazići. Slučajevi demoliranja kuća i pokućstva, neiskustvo u poljoprivrednim poslovima, angažovanje kolonista u obaveznom otkupu predstavljali su samo neke od razloga koji su izazivali netrpeljivost starosedelaca. Prema naseljenicima su se ophodili sa visine, smatrajući ih ,,primitivcima“. ${ }^{162}$ Njihove postupke nazivali su ,divljim“ $i$, šumskim“, što je dovelo do obostranog omalovažavanja. ${ }^{163}$ Netrpeljivosti su se katkad pretvarale u čarke koje su izbijale na igrankama i u kafanama. Kolonisti su teško podnosili uvrede o svojoj „zaostalosti“, pa su upadali u tuče nazivajući starosedeoce ,kukavicama“. ${ }^{164}$ Poremećenim odnosima doprinosili su i sami kolonisti budući da su nastavili da se okupljaju oko svojih organizacija, pa čak i da organizuju svoje ,narodne odbore“ koji su u njihovim međusobnim odnosima predstavljali ,jedinu vlast“. ${ }^{65}$

Za prihvatanje novog načina života i uklapanje u novu sredinu bilo je potrebno vreme. Kolonisti su najlakše odbacili svoju nošnju i prihvatili novo odelo. ${ }^{166}$ Porodične zadruge su se raspadale, položaj žena se popravio, ${ }^{167}$ kuće i dvorišta su sređivani i održavani, ${ }^{168}$ prihvaćen je gradski nameštaj, ${ }^{169}$ poljoprivredna proizvodnja unapređena, razvijene su nove radne navike i prihvaćene povrtarske $\mathrm{i}$ industrijske kulture. ${ }^{170}$ Navikavanje na život u ravnici dovelo je i do poboljšavanja međususedskih odnosa i smanjivanja broja konfliktnih situacija. Brakovi između doseljenika i starosedelaca postali su češći, ${ }^{171}$ a deagrarizacija i zapošljavanje sve većeg broja kolonista u fabrikama stvorili su veće mogućnosti za komunikaciju i interakciju sa lokalnim stanovništvom. ${ }^{172}$ Uprkos delimičnoj integraciji kolonista, deo starosedelačkog življa je i dalje izbegavao da se „meša“ sa naseljenicima. ${ }^{173}$ Štaviše, kolonisti su još dugo negovali veze sa zavičajem i odnose sa svojim zemljacima u Vojvodini, tako da su istinska prijateljstva između starosedelačkog stanovništva i kolonista i početkom 60 -ih godina predstavljala retkost. ${ }^{174}$

${ }^{160}$ B. Petranović, Političke i pravne prilike..., 410.

161 AJ, 97-9-60, Br. 34, 30. 1. 1946.

162 M. Vasović, $n$. d., 159.

163 V. Đurić, n. d., 16.

${ }^{164}$ V. Katić, $n$. d., 47. Videti i: М. Бошковић и Митар Шутић, $\mu . d ., 183$. V. Đurić, $n$. d., 16.

165 B. Petranović, Političke i pravne prilike..., 69.

${ }^{166}$ V. Katić, $n$. $d$., 28; M. Vasović, $n$. $d$., 40.

167 V. Đurić, n. d., 17.

168 Д. Николић, н. д., 241.

169 J. Trifunovski, O posleratnom naseljavanju stanovništva iz NR Makedonije u tri banatska naselja, 22.

${ }^{170}$ V. Jeržabek, $n . d ., 44$.

${ }^{171}$ V. Đurić, $n$. d., 17.

172 Darinka M. Kostić, Promene u društvenom životu kolonista. Integracija agrarnih kolonista sa starosedeocima u Vrbasu: tendencije prostorne pokretljivosti agrarnih kolonista $i$ njihovih zemljaka (Beograd: Institut društvenih nauka, 1963), 23.

${ }^{173}$ Borislav Dimković, „Međusobni odnosi i uticaji starosedelaca i kolonista posle II svetskog rata“, Sociologija i prostor, br. 5-6, (1964), 107.

${ }^{174}$ V. Jeržabek, $n$. d., 43. 


\section{REFERENCE}

- Bjeljac Željko, i Aleksandra Terzić. „Migracije na teritoriji Vojvodine 19451948. Uzroci i demografsкe posledice“. U: 1945. Kraj ili novi početak. Urednik Zoran Janjetović, 375-402. Beograd: Institut za noviju istoriju Srbije, Muzej žrtava genocida, 2016.

- Bondžić, Dragomir. „Kordun u socijalističkoj Jugoslaviji (1945-1990)“. U: Kordun. Od Vojne granice do Republike Srpske Krajine 1881-1995. Urednik Momčilo Pavlović, 317-478. Beograd: Institut za savremenu istoriju, 2018. https://doi.org/10.29362/2275.bon.317-478

- Bošković Milovan, i Mitar Šutić. Dva zavičaja. Dokumenat o jednoj seobi. Povodom 60 godina naseljavanja Gajdobre. Gajdobra: Ogranak Vukove zadužbine, 2005.

- Dimković, Borislav. „Međusobni odnosi i uticaji starosedelaca i kolonista posle II svetskog rata“. Sociologija i prostor, br. 5-6, (1964), 100-109.

- Dobrivojević Tomić, Ivana. „U potrazi za boljom budućnošću. Naseljavanje kolonista u prvim godinama nakon Drugog svetskog rata“. U: Drugi svetski rat - 75 godina kasnije, u pripremi za štampu.

- Đurđev, Branislav. Posleratno naseljavanje Vojvodine. Metodi i rezultati demografske analize naseljavanja Vojvodine u periodu 1945-1981. Novi Sad: Matica srpska, 1995.

- Đurić, Vladimir. Najnovije naseljavanje Bačke kolonistima iz Hrvatske. Novi Sad: Matica srpska, 1960.

- Gaćeša, Nikola. Agrarna reforma i kolonizacija u Jugoslaviji 1945-1948. Novi Sad: Matica srpska, 1984.

- Gudac Dodić, Vera. Agrarna politika i seljaštvo u Srbiji 1945-1953. Beograd: Zavod za udžbenike i nastavna sredstva, 1999.

- Jeržabet, Vinko. „Kolonizacija u Vršcu“. Sociologija sela, br. 9, (1965), 32-46.

- Katić, Vesna. „Promene društvenog i običajnog života kolonista iz Bosanske Krajine u vojvođanskim selima“. Magistarski rad, Univerzitet u Beogradu, Filozofski fakultet, Odeljenje za etnologiju, 1985.

- Kostić, Darinka M. Promene u društvenom životu kolonista. Integracija agrarnih kolonista sa starosedeocima u Vrbasu: tendencije prostorne pokretljivosti agrarnih kolonista i njihovih zemljaka. Beograd: Institut društvenih nauka, 1963.

- Laušić, Ante. „Osnovne značajke kolonizacijskih procesa na jugoslavenskom području 1918-1948“. Migracijske teme, 5, br. 1, (1989), 27-42.

- Lekić, Bogdan. Agrarna reforma i kolonizacija u Jugoslaviji 1945-1948. Beograd: Arhiv Srbije, 1997.

- Mitrović, Momčilo. Društveno-ekonomske promene i organizacija upravljanja privredom u Srbiji 1944-1952. Beograd: Institut za istoriju radničkog pokreta Srbije, 1988. 
- Nikolić, Desanka. „Preobražaji - etnološki pogled“. U: Bačko Dobro Polje gorštaci u ravnici. Urednik Obren Blagojević, 233-275. Beograd: Etnografski institut SANU, 1979.

- Petranović, Branko. Političke i pravne prilike za vreme privremene vlade DFJ. Beograd: Institut društvenih nauka, 1964.

- Petranović, Branko. Politička i ekonomska osnova narodne vlasti u Jugoslaviji za vreme obnove. Beograd: Institut za savremenu istoriju, 1969.

- Petranović, Branko (prir.). Zapisnici sa sednica Politbiroa Centralnog komiteta KPJ (11. 6. 1945 - 7. 7. 1948). Beograd: Arhiv Jugoslavije, Službeni list SRJ, 1995.

- Petranović Branko, i Momčilo Zečević. Agonija dve Jugoslavije. Beograd: Zaslon, 1991.

- Trifunovski, Jovan. O posleratnom naseljavanju stanovništva iz NR Makedonije u tri banatska naselja - Jabuka, Kačarevo i Glogonj. Novi Sad: Matica srpska, 1958.

- Trifunovski, Jovan. Posleratno naseljavanje stanovništva u Rumi, Hrtkovcima i Nikincima. Novi Sad: Matica srpska, 1958.

- Vasović, Milorad. Najnovije naseljavanje Crnogoraca u nekim bačkim selima. Novi Sad: Matica srpska, 1959.

IVANA DOBRIVOJEVIĆ TOMIĆ, PhD, Senior Research Associate Institute for Contemporary History

Belgrade, Republic of Serbia

ivanadobrivojevic@hotmail.com

\section{PROBLEMS IN SETTLING AND ADAPTING OF COLONISTS TO LIFE IN VOJVODINA IN THE FIRST YEARS AFTER WORLD WAR TWO}

The Decision to Confiscate German-Owned Property (1944), the Law on Agrarian Reform and Colonization (August 1945) and the Decree on the Implementation of Veterans' Settlement (1945) provided a legal framework for the colonization of Vojvodina. People from the outback regions applied for colonization in large numbers since it was believed that migration guaranteed deliverance from decades of dearth and poverty. The journey of the colonists was fraught with numerous difficulties, primarily due to poor organization and frequent changes of plans. The distribution of houses, cattle, and inventory was done by local commissions. The bias of these commissions was obvious. Thus, the division of houses and inventory was accompanied by great social injustices. Some families were housed in buildings with electrical installations, while others had to settle into houses without floors. Such actions caused indignation and revolt among the colonists. Dissatisfied with their new life, as many as 4,000 families decided to return. Those who remained needed time to adapt to the new way of life. With time, big families disintegrated, the position of women improved, new work habits were developed, and neighborly relations became better.

KEYWORDS: Yugoslavia, Vojvodina, Migrations, Colonists, Autocolonists 